\section{Editors' Report for Volume 130 (2016)}

Mailing dates for the four issues in volume 130 are as follows: 17 June 2016; 30 September 2016; 16 December 2016; 21 April 2017. Summaries of the distribution of memberships in the Ottawa Field-Naturalists' Club, who all receive access to The Canadian Field-Naturalist, and subscribers to The Canadian Field-Naturalist for 2016 are provided in Table 1 , along with comparison numbers for volume 129. Institutional subscribers potentially represent many thousands of users. The number of Articles and Notes in volume 130 is summarized in Table 2 by topic. Totals for book reviews and new titles are given in Table 3, and the distribution of content by page totals per issue is provided in Table 4 . Sixty-nine manuscripts were submitted to The Canadian Field-Naturalist in 2016: only 25 of these were submitted by email with all those after July submitted using the Online Journal System. Of the 69 submissions, $57(82.6 \%)$ were accepted for publication and either published or undergoing further revision and review, nine were not accepted upon initial submission or review, two were not accepted upon revision, and one was withdrawn. A total of 30 Articles, 20 Notes, and two Tributes were published in 2016.

Dwayne Lepitzki began the transition to Editor-in-Chief from Carolyn Callaghan with issue 2. Amanda Martin, Assistant Editor, edited content, proofread galleys, compiled the "Upcoming Meetings and Workshops" section of the News and Comments, and sent and received author order and transfer of copyright forms. Sandra Garland and, beginning with issue 4, John Wilmshurst proofed and copy edited manuscripts. Wendy Cotie typeset galleys, provided corrections for page proofs, and created pdfs. Roy John and, beginning with issue 3, Barry Cottam requested books for review, selected reviewers, edited submitted reviews, and prepared the new titles listings. Ken Young assumed the duties for managing subscriptions and page charge invoices from Eleanor Zurbrigg with issue 2. William Halliday, Journal Manager and Webmaster, provided digital content to subscribers, posted tables of contents, abstracts, and pdfs on The Canadian Field-Naturalist website, and prepared the Index. Our Associate Editors managed manuscripts, provided reviews and recommendations, and guided authors through the revisions process. The Publication Committee, chaired by Jeff Saarela and consisting of Annie Bélair, Dan Brunton, Carolyn Callaghan, Paul Catling, Barry Cottam, Tony Gaston (resigned late in 2016), William Halliday, Diane Kitching, Dwayne Lepitzki, Amanda Martin, Karen McLachlan Hamilton, Frank Pope, and David Seburn effectively guided the operation of the journal. We are indebted to our very dedicated team.
TABLE 2. Number of research articles and notes published in The Canadian Field-Naturalist, Volume 130 (Volume $129)$, by major field of study.

\begin{tabular}{lcrr}
\hline \hline Subject & Articles & Notes & Total \\
\hline Mammals & $9(7)$ & $10(6)$ & $19(13)$ \\
Birds & $4(7)$ & $5(5)$ & $9(12)$ \\
Amphibians and & & & \\
$\quad$ Reptiles & $4(2)$ & $0(3)$ & $4(5)$ \\
Fishes & $4(4)$ & $2(2)$ & $6(6)$ \\
Plants & $4(5)$ & $1(2)$ & $5(7)$ \\
Insects & $2(1)$ & $0(0)$ & $2(1)$ \\
Non-insect & $3(2)$ & $2(1)$ & $5(3)$ \\
Invertebrates & $30(28)$ & $20(19)$ & $50(47)$ \\
\hline Total &
\end{tabular}

TABLE 3. Number of reviews and new titles published in the Book Review section of The Canadian Field-Naturalist, Volume 130 (Volume 129), by topic.

\begin{tabular}{lrc}
\hline \hline & Reviews & New Titles \\
\hline Zoology & $10(18)$ & $45(26)$ \\
Botany & $3(3)$ & $16(2)$ \\
Miscellaneous & $9(14)$ & $32(19)$ \\
\hline Total & $22(35)$ & $93(47)$ \\
\hline \hline
\end{tabular}

The following Associate Editors managed, assessed, and reviewed manuscripts published in volume 130: P. M. Catling, Agriculture and Agri-Food Canada, Ottawa ON (4 manuscripts); F. Chapleau, University of Ottawa, Ottawa ON (4); F. R. Cook, Emeritus Research Associate, Canadian Museum of Nature, Ottawa ON (5); J. Foote, Algoma University, Sault Ste. Marie ON (4); G. Forbes, University of New Brunswick, Fredericton NB (1); A. J. Gaston, Environment Canada (emeritus), Ottawa ON (4); T. Jung, Yukon Government, Whitehorse YT (3); D. F. McAlpine, New Brunswick Museum, Saint John NB (5); G. Mowat, government of British Columbia, Nelson BC (3); D. W. Nagorsen, Mammalia Biological Consulting, Victoria BC (7); M. Obbard, Ontario Ministry of Natural Resources and Forestry, Peterborough ON (3); C. Renaud, Canadian Museum of Nature, Ottawa ON (2); J. M. Saarela, Canadian Museum of Nature, Ottawa ON (3); J. Skevington, Agriculture and Agri-Food Canada, Ottawa ON (2).

The following referees reviewed manuscripts published in volume 130 (number of manuscripts reviewed $>1$ in parenthe-

TABLE 1. The 2016 (2015) circulation of The Canadian Field-Naturalist. Compiled by Ken Young from the subscription list for $130(4)$.

\begin{tabular}{lccrrrrrr}
\hline \hline Subscriber Type & \multicolumn{2}{c}{ Canada } & \multicolumn{2}{c}{ USA } & \multicolumn{2}{c}{ Other } & \multicolumn{2}{c}{ Total } \\
\hline OFNC Members & 58 & $(61)$ & 3 & $(3)$ & 1 & $(1)$ & 62 & $(65)$ \\
Subscriptions: & 21 & $(12)$ & 6 & $(6)$ & 1 & $(0)$ & 28 & $(18)$ \\
$\quad$ Individual & 84 & $(107)$ & 116 & $(158)$ & 13 & $(19)$ & 213 & $(284)$ \\
$\quad$ Institutional & 163 & $(180)$ & 125 & $(167)$ & 15 & $(20)$ & 303 & $(367)$ \\
\hline Total & & & & &
\end{tabular}


TABLE 4. Number of pages per section published in The Canadian Field-Naturalist, Volume 130 (Volume 129), by issue.

\begin{tabular}{lccccc}
\hline \hline & \multicolumn{3}{c}{ Issue } & \multicolumn{1}{c}{} \\
\cline { 2 - 5 } & 1 & 2 & 3 & 4 & Total \\
\hline Editorials/Editor's Report & $0(0)$ & $3(3)$ & $0(0)$ & $0(0)$ & $3(3)$ \\
Articles & $63(59)$ & $73(66)$ & $43(44)$ & $59(72)$ & $238(241)$ \\
Notes & $18(30)$ & $14(16)$ & $14(30)$ & $21(14)$ & $67(90)$ \\
Tributes & $0(7)$ & $0(0)$ & $0(0)$ & $18(0)$ & $18(7)$ \\
Book Reviews* & $8(15)$ & $4(10)$ & $9(14)$ & $11(4)$ & $32(43)$ \\
News and Comment & $1(3)$ & $2(9)$ & $3(2)$ & $4(2)$ & $10(16)$ \\
Reports† & $0(0)$ & $4(0)$ & $15(13)$ & $0(5)$ & $19(18)$ \\
Erratum & $0(0)$ & $0(0)$ & $0(1)$ & $0(0)$ & $0(1)$ \\
Index & $-(-)$ & $-(-)$ & $-(-)$ & $7(7)$ & $7(7)$ \\
Total & $90(114)$ & $100(104)$ & $84(104)$ & $120(104)$ & $394(426)$ \\
\hline \hline
\end{tabular}

*Includes reviews and new titles.

$\dagger$ Includes Annual Business Meeting Minutes, Annual Committee Reports, Financial Statements, Awards.

ses): Ray Alisauskas, Environment and Climate Change Canada; Mike Anderson, Ducks Unlimited Canada (emeritus); Carl D. Anthony, John Carroll University; Robin Baird, Olympia WA; Peter Ball, University of Toronto; Shannon BarberMeyer, US Geological Survey; Erin Bayne, University of Alberta; John Benson, University of Nebraska-Lincoln; Jennifer Bigman, Simon Fraser University; Anne Bjorkman, German Centre for Integrative Biodiversity Research, Leipzi; Gabriel Blouin-Demers, University of Ottawa; Jeff Bowman, Ontario Ministry of Natural Resources and Forestry; Dan Brunton, Ottawa ON (2); Joseph Bump, Michigan Technological University; Jonathan Choquette, Guelph ON; Jonathan Cormier, New Brunswick Department of Natural Resources; Aurélie Cosandey Godin, Dalhousie University; Hugo Cota, University of Saskatchewan; Brenda Dale, Environment and Climate Change Canada; Christina Davey, Trent University; Dick Dekker, Edmonton AB; A. W. Diamond, University of New Brunswick; Mark Edwards, Royal Alberta Museum; Mark Elbroch, Panthera NY; Marco Festa-Bianchet, Université de Sherbrooke; Graham Forbes, University of New Brunswick; Bruce Ford, University of Manitoba; Robert Forsyth, Kamloops BC; Jochen Gerber, The Field Museum; John Gilhen, Nova Scotia Museum of Natural History (2); Scott Gillingwater, Upper Thames River Conservation Authority; Emily Gonzales, Parks Canada; Karen Graham, Foothills Research Institute; Patrick Gregory, University of Victoria; Samuel Haché, Canadian Wildlife Service; Gavin Hawke, Royal British Columbia Museum; Douglas Heard, University of Northern British Columbia; Raymond Hutchinson, Ottawa ON; Louis Imbeau, Université du Québec en Abitibi-Témiscamingue; James Irvine, Fisheries and Oceans Canada; S. J. Iverson, Canadian Wildlife Service; Chris Johnson, University of Northern British Columbia; Tom Johnston, Ontario Ministry of Natural Resources and Forestry/Laurentian University; Tom Jung, Government of Yukon; Ernest Keeley, Idaho State University; Nicola Koper, University of Manitoba; Piia Kukka, University of Alberta; Christopher Kyle, Trent University; Jeffery Larkin, Indiana University of Pennsylvania; Shawn Larson, Seattle Aquarium; Jim Leafloor, Canadian Wildlife Service; Lisa-Marie Leclerc, Government of Nunavut; Weiming Li, Michigan State University; Staffan Lindgren, University of Northern British Columbia; Todd Mahon, Edmonton AB; David Nagorsen, Victoria BC; Nicholas Mandrak, University of Toronto; Nigel Marley, United Kingdom; Catherine Meckleburg, Auke Bay AK; Randall F. Miller, New Brunswick Museum; W. A. Montevecchi, Memorial University of Newfoundland and Labrador; David Murray, University of Alaska; Fraser
Neave, Fisheries and Oceans Canada; Dianne R. Nelson, East Tennessee State University; Erica Newton, Ontario Ministry of Natural Resources and Forestry; Martyn Obbard, Ontario Ministry of Natural Resources and Forestry (retired); Colleen Olfenbuttel, North Carolina Wildlife Research Commission; Ken Otter, University of Northern British Columbia; Kristiina Ovaska, Victoria BC; Brent Patterson, Ontario Ministry of Natural Resources and Forestry / Trent University (2); Tim Pearce, Carnegie Museum of Natural History (2); Bruce Pond, Ontario Ministry of Natural Resources and Forestry; Paul Pratt, Wheatley ON; Tanya Pulfer, Ontario Nature; Randall Reeves, Hudson QC; Darryl Reynolds, British Columbia Ministry of Forests, Lands and Natural Resource Operation; Tony Reznicek, University of Michigan; Jim Richards, Nunavut Bird Checklist; Mark Ridgway, Ontario Ministry of Natural Resources and Forestry; Mike Rodway, Gold Bridge BC; Rick Rosatte, Ontario Ministry of Natural Resources and Forestry; Dolph Schluter, University of British Columbia; Fred Schueler, Bishop Mills ON; Helen Schwantje, British Columbia Ministry of Forests, Lands and Natural Resource Operations; Spencer Sealy, University of Manitoba; David Seburn, Ottawa ON; Dale Seip, British Columbia Ministry of Environment; Philipp Semenchuk, University of Tromso; Tamara Smith, US Fish and Wildlife Service; Tyler Smith, Agriculture and Agri-Food Canada; Stuart Slattery, Ducks Unlimited Canada; Michael Steele, Wilkes University; Tom Sullivan, University of British Columbia; Heidi Swanson, University of Waterloo; Tara Szkorupa, British Columbia Ministry of Forests, Lands and Natural Resource Operations; Ken Tape, University of Alaska - Fairbanks; Phil Ward, University of California Davis; Doug Watkinson, Fisheries and Oceans Canada; Dave Zanatta, Central Michigan University.

The journal was printed at Gilmore Printers, Ottawa. Thanks to Guylaine Duval of Gilmore Printers for overseeing production and printing. We are grateful to The Ottawa FieldNaturalists' Club President Fenja Brodo and the club's Board of Directors for their support of the journal. We are also grateful to all of the individual subscribers and authors who support our team as we strive to provide a high-quality scientific journal on natural history, field biology, and ecology. Finally, we thank our families/partners for being patient and supportive throughout many long days, evenings, and weekends of working on the journal.

DWAYNE LEPITZKI and CAROLYN CALLAGHAN, Editors-in-Chief;

AMANDA MARTIN, Assistant Editor 